\title{
ACCURACY OF A DUAL PATH PLATFORM (DPP) SYPHILIS SCREEN \& CONFIRM ASSAY FOR SIMULTANEOUS DETECTION OF NONTREPONEMAL AND TREPONEMAL ANTIBODIES IN PATIENTS WITH ACQUIRED SYPHILIS
}

\author{
AVALIAÇÃO DA ACURÁCIA DO KIT DE TESTE RÁPIDO EM PLATAFORMA DE \\ DUPLO PERCURSO (Teste Rápido DPP ${ }^{\circledR}$ Sífilis Duo - Bio-Manguinhos) PARA DETECÇÃO \\ DE ANTICORPOS TREPONÊMICOS E NÃO TREPONÊMICOS EM PACIENTES COM \\ SÍFILIS ADQUIRIDA
}

\author{
Ricardo Cristiano Brum ${ }^{1}$ \\ Ricardo Wagner de Almeida ${ }^{2}$ \\ Janaína Reis Xavier ${ }^{3}$ \\ Elizabeth Maciel de Albuquerque ${ }^{4}$ \\ Ramon Lemos Calaça das Neves ${ }^{5}$ \\ Hugo Garcia Tonioli Defendi 6 \\ Maria de Lourdes Sousa Maia ${ }^{7}$ \\ Tatiana Guimarães de Noronha ${ }^{8}$
}

\begin{abstract}
We evaluate the performance of a point-of-care immunochromatographic test DPP ${ }^{\circledR}$ Syphilis Screen \& Confirm Bio-Manguinhos Assay in the whole blood, sera, and plasma of patients with acquired syphilis in. The population was composed by adults stratified in three groups: HIV $(\mathrm{N}=174)$, pregnant women $(\mathrm{N}=170)$ and neither pregnant nor HIV infected $(\mathrm{N}=149)$. The results from the dual test were compared to the combination of TPHA+/VDRL $\geq 1: 8$. The results of sensitivity in people infected with HIV were $100 \%$ in whole blood, sera, and plasma, and the specificity ranged from 91.9-93.1\%. The results of sensitivity in pregnant women were $100 \%$ in whole blood, sera, and plasma, and the specificity ranged from98.2-99.4\%. The results of sensitivity in people neither pregnant nor HIV infected were $80 \%$ in whole blood and $100 \%$ in sera and plasma. The specificity in whole blood, sera, and plasma, ranged from 96.5- 97.2\%. The DPP ${ }^{\circledR}$ Syphilis Screen \& Confirm Bio-Manguinhos Assay showed good performance in detecting treponemal and nontreponemal antibodies in whole blood, serum and plasma, although the study has showed syphilis prevalences lower than previously estimated, affecting the positive predictive value calculation. These results indicate that the dual test could be used as an alternative in the diagnosis of syphilis.
\end{abstract}

Keys words: Syphilis, Rapid Tests, Dual Path Platform (DPP)

\footnotetext{
${ }^{1}$ Instituto de Tecnologia em Imunobiológicos /Bio-Manguinhos/Fiocruz. E-mail: ricardo.brum@gmail.com

${ }^{2}$ Instituto de Tecnologia em Imunobiológicos /Bio-Manguinhos/Fiocruz.

3 Instituto de Tecnologia em Imunobiológicos/Bio-Manguinhos/Fiocruz.

${ }^{4}$ Instituto de Tecnologia em Imunobiológicos/Bio-Manguinhos/Fiocruz.

5 Instituto de Tecnologia em Imunobiológicos/Bio-Manguinhos/Fiocruz.

${ }^{6}$ Instituto de Tecnologia em Imunobiológicos/Bio-Manguinhos/Fiocruz.

7 Instituto de Tecnologia em Imunobiológicos/Bio-Manguinhos/Fiocruz.

${ }^{8}$ Instituto de Tecnologia em Imunobiológicos/Bio-Manguinhos/Fiocruz.
} 
RESUMO: Foi avaliado o desempenho de um teste imunocromatomatográfico (teste rápido) utilizado como "point of care", chamado DPP ${ }^{\circledR}$ Sífilis Screen \& Confirm Bio-Manguinhos, em amostras de sangue total, soro e plasma, de pacientes com sífilis adquirida. A população foi composta por adultos estratificados em três grupos: HIV $(N=174)$, gestantes $(N=170)$ e população geral, não gestante e não HIV ( $\mathrm{N}=\mathrm{I} 49)$. Os resultados do teste de duplo percurso foram comparados por meio da combinação com o teste TPHA+/VDRL $\geq 1: 8$. Os resultados da sensibilidade em pessoas infectadas pelo HIV foram I0o\% em sangue total, soro e plasma, e a especificidade variou de 91,9 a 93,1\%. Os resultados da sensibilidade em gestantes foram ıоo\% em sangue total, soro e plasma, e a especificidade variou de 98,2 a 99,4\%. O resultado de sensibilidade na população geral foi de $80 \%$ em sangue total e Ioo\% em soro e plasma. A especificidade em sangue total, soro e plasma, variou de 96,5 a 97,2\%. O ensaio DPP ${ }^{\circledR}$ Sífilis Screen \& Confirm (para triagem e confirmação) de Bio-Manguinhos mostrou bom desempenho na detecção de anticorpos treponêmicos e não-treponêmicos em sangue total, soro e plasma, embora o estudo tenha mostrado prevalências de sífilis inferiores às estimadas anteriormente, afetando o cálculo do valor preditivo. Esses resultados indicam que o teste duplo para sífilis pode ser usado como uma alternativa no diagnóstico de sífilis.

Palavras-chave: Sífilis, Testes Rápidos, Plataforma dual path (DPP)

\section{INTRODUCTION}

Syphilis is a curable infection disease caused by Treponema pallidum. With the introduction of penicillin in the 1940s, there was a sharp decline in the incidence of both acquired syphilis as congenital syphilis. However, the incidence of the disease rose again sharply in the 1980s with the popularity of drugs such as cocaine and crack and greater sexual liberalization (1,2). From 1986-1990, the syphilis rate has almost doubled, reaching a peak of 53.8 cases per 100,000 inhabitants in 1990. In 2005-2013, the number of cases of primary and secondary syphilis reported each year in the United States almost doubled from 8.7 to 16.6 ; the annual rate increased from 2.9 to 5.3 cases per 1oo,ooo inhabitants (3).

Data from epidemiological reports of STD / AIDS of the Brazilian Ministry of Health ${ }^{\text {a }}$ of Health has shown an annual increase in the number of reported cases of syphilis in pregnancy, I4,32I cases in 20II. A proper diagnosis during pregnancy is an important challenge for the control of congenital syphilis $(4,5,6)$.

Serological tests remain the most widely used method to establish the diagnosis of syphilis, are carried out in laboratories with trained personnel, refrigerators for storage of reagents and electricity to the necessary equipment (refrigerator, centrifuges and stirrers). However, these facilities are not available in remote areas and blood and serum samples need to be transported to regional or local stations that can be tested. In addition, the test results are often available only days or weeks after the tests. If those who have been tested do not return to get their results, they will 
not be treated and continue to transmit the infection. In many developing countries, the treatment is not done just by the fact that patients do not return to get their results $(7,8)$.

In order to test and begin treatment on the same day, many rapid tests for syphilis have been developed and commercialized recently. However, none of the current tests distinguishes between active infection and past infection that has already been treated, since antibodies to treponemal antigens are retained for years (9). The continued use of these rapid tests, particularly in populations with high prevalence of syphilis (eg .: female sex workers and men who have sex with men), result in repeated treatment or when the patients are subsequently subjected to a non-treponemal test it can frequent exclude the diagnosis of syphilis, if it is negative. These issues often result in distrust between test providers and target populations.

$\mathrm{DPP}^{\circledR}$ Syphilis Screen \& Confirm Assay is a multiplex test that incorporates the Treponemal as well as a Non-Treponemal parameter, thereby better enabling the detection and differentiation of active infections from past infections in one rapid, point-of-care device.

\section{Methods}

\section{Study Design}

This is a sectional study among pregnant women, HIV-infected individuals and neither pregnant nor HIV infected people referred to Maternity Hospital Carmela Dutra, Maternity Hospital Fernando Magalhães, General Hospital of Nova Iguaçu, and Hospital School São Francisco de Assis/ UFRJ. The maternities offer comprehensive pregnancy and prenatal care, including specialized prenatal diagnostic services and the other hospitals are reference centres that receive persons suspected to be infected with HIV. 517 individuals were potentially eligible (for routine syphilis screening according to routine practices, with age between 13 and 59 years) to participate in the study and $49 \mathrm{I}$ individuals were included and analyzed in this study. The groups were defined as: (I) infected with HIV, (2) pregnant women attending antenatal consultations in the centre, (3) neither pregnant nor HIV infected. All subjects gave their informed consent for inclusion before they participated in the study. We conducted the study in accordance with the principles of good clinical practice (GCP), and the protocol was approved by the Fiocruz Ethics Committee under the number 10862312.5.1001.5248.

\section{Laboratory Investigations}

The DPP ${ }^{\circledR}$ Syphilis Screen \& Confirm Assay used in this study was developed by Chembio Diagnostic Systems, Inc (Medford, NY) and is manufactured by BioManguinhos (Rio de Janeiro, Brazil) through a technology transfer agreement with the Brazilian Ministry of Health. The test 
kits were stored in a temperature-controlled setting, with the temperature being both monitored and recorded. The test description has been reported (IO, II). The phlebotomists were trained in person on-site by Fiocruz staff. Blood samples were obtained by venipuncture using to $\mathrm{mL}$ vacutainer tubes (BD, Plymouth, NJ, USA) and clotted. All serum samples were stored at $-20^{\circ} \mathrm{C}$ until analysis. The serum samples were tested by the Venereal Disease Research Laboratory (VDRL) and subjected to the Treponema pallidum hemagglutination assay (TPHA), in accordance with the manufacturer's instructions. For the POC Syphilis Screen \& Confirm assay, ro $\mu \mathrm{L}$ of finger stick or venipuncture whole blood and $5 \mu \mathrm{L}$ of serum or plasma were added directly to well i followed by two drops of Running.

Buffer. After five minutes, five drops of Running Buffer were added to Well 2. The results were read 15 minutes after the addition of buffer to Well 2. If there was no control line after io minutes from addition of Running Buffer to "Buffer" Well 2, the test is Invalid. This means there was a problem with the test. If sample was reactive for Treponemal antibodies only, it suggested past or a treated case. If sample was reactive for non-Treponemal antibodies only, it suggested a biological false positive result, and if sample was reactive for both Treponemal and non-Treponemal antibodies, it suggested active $\&$ untreated disease. The result was negative when sample contained no detectable antibodies to both Treponemal and non-Treponemal antigens (I2).

\section{Statistical Analysis}

We estimated the sensitivity and specificity of the DPP ${ }^{\circledR}$ Syphilis Screen \& Confirm Assay by comparing the performance of the DPP treponemal result ( $\mathrm{T}_{I}$ component) to reference treponemal serology (TPHA) and by comparing the performance of the DPP nontreponemal result ( $T_{2}$ component) to reference nontreponemal test (VDRL $\left.\geq 1: 8\right)$. We classified the outcome of the DPP test correspondingly, as defining active infection (both elements positive), comparing the results to reference serology (TPHA+VDRL $\geq 1: 8)$. We calculated the overall agreement between the outcome of the DPP ${ }^{\circledR}$ Syphilis Screen \& Confirm Assay and the reference serology.

The sensitivities and specificities for DPP ${ }^{\circledR}$ Syphilis Screen \& Confirm Assay were calculated by standard methods and compared between prespecified groups of participants and sample type. A kappa ( $\mathrm{k}$ ) value for the agreement between the POC test and reference tests was calculated for each test as a summation of the overall performance using software IBM SPSS Statistics 20 (Armonk, NY: IBM Corp.) (13). For the analyses presented here, DPP POC test sensitivity refers the treponemal and nontreponemal lines result compared to reference TPHA+VDRL $\geq 1: 8$. 


\section{Results}

The sample was 174 (35.4\%) HIV infected (GI), included from October to December 2014 (median age $=33.1$ years, no history of syphilis or current clinical symptoms of syphilis); 168 (34.2\%) pregnant women $\left(\mathrm{G}_{2}\right)$, included during January 2015 (median age $=28.5$ years, no history of syphilis or current clinical symptoms of syphilis); 149 (30.3\%) neither pregnant women nor HIV infected $\left(G_{3}\right)$, included from November to December 2014 (median age $=34.8$ years, no history of syphilis or current clinical symptoms of syphilis). The prevalence of active syphilis (and untreated disease) was $0.6 \%$ in $\mathrm{G}_{1}, 0.6 \%$ in $\mathrm{G}_{2}$, and $3.4 \%$ in $\mathrm{G}_{3}$.

\section{DPP ${ }^{\circledR}$ Syphilis Screen \& Confirm Assay in HIV infected (GI)}

The sensitivity of non-treponemal test in whole blood, serum and plasma samples, when compared to VDRL positivity (titer I: $\mathrm{I}$ ) was $83.3 \%$ (95\% CI) and the specificity ranged from 95.7 to 96.9\%. The sensitivity improves to 100\% when the gold standard comparison is TPHA positive and a VDRL titer of $1: 8$ and the specificity ranges from 90.8 to $91.9 \%$. The sensitivity of the treponemal test in whole blood, serum and plasma, when compared to TPHA ranged from 57.5 to $73.2 \%$ (95\% $\mathrm{CI})$ and the specificity ranged from 96.3 to $97, \mathrm{I} \%$. When participants who were nontreponemal/treponemal rapid test positive were compared to TPHA+VDRL r:8, the sensitivity was $100 \%$ in whole blood, serum and plasma and the specificity ranged from 91.9 to $93.1 \%$ (95\% CI).

\section{DPP ${ }^{\circledR}$ Syphilis Screen \& Confirm Assay in pregnant women $\left(G_{2}\right)$}

The sensitivity of non-treponemal test in whole blood, serum and plasma samples, when compared to VDRL positivity (titer I:I) ranged from 50 to $75 \%(95 \% \mathrm{CI})$ and the specificity ranged from 98.8 to $100 \%$. The sensitivity improves to $100 \%$ when the gold standard comparison is TPHA positive and a VDRL titer of $\mathrm{r}: 8$ and the specificity ranges from 97.6 to $99.4 \%$. The sensitivity of the treponemal test in whole blood, serum and plasma, when compared to TPHA ranged from 91.7 to $100 \%(95 \% \mathrm{CI})$ and the specificity ranged from 98.7 to $99.4 \%$. When participants who were nontreponemal/treponemal rapid test positive were compared to TPHA+VDRL $1: 8$, the sensitivity was $100 \%$ in whole blood, serum and plasma and the specificity ranged from 98.2 to $99.4 \%$ (95\% CI).

\section{DPP ${ }^{\circledR}$ Syphilis Screen \& Confirm Assay in neither pregnant women nor HIV infected $\left(\mathrm{G}_{3}\right)$}

The sensitivity of non-treponemal test in whole blood, serum and plasma samples, when compared to VDRL positivity (titer I: I) ranged from 54.5 to $72.7 \%$ (95\% CI) and the specificity ranged from 97.8 to $98.6 \%$. The sensitivity improves to $80 \%$ in whole blood and $100 \%$ in serum and 
plasma samples when the gold standard comparison is TPHA positive and a VDRL titer of $\mathrm{r}: 8$ and the specificity is 96.5 in whole blood, serum, and plasma samples. The sensitivity of the treponemal test in whole blood, serum and plasma, when compared to TPHA ranged from 85 to $95 \%$ (95\% CI) and the specificity ranged from 97.9 to $100 \%$. When participants who were nontreponemal/treponemal rapid test positive were compared to TPHA+VDRL $1: 8$, the sensitivity was $80 \%$ in whole blood and $100 \%$ in sera and plasma the specificity ranged from 96.5 to $97,2 \%$ (95\% CI: ).

Table r: Overall Sensitivity and Specificity of DPP ${ }^{\circledR}$ Syphilis Screen \& Confirm by TPHA+VDRL r:8

\begin{tabular}{|ccccccc|}
\hline \multicolumn{4}{c}{ Sensitivity $(95 \%$ CI) } & \multicolumn{3}{c|}{ Specificity (95\% CI) } \\
& whole blood & Serum & Plasma & whole blood & Serum & Plasma \\
G1 & $100(0,99-1,00)$ & $100(0,99 ; 1,00)$ & $100(0,99 ; 1,00)$ & $93.1(0,89 ; 0,96)$ & $91.9(0,87 ; 0,96)$ & $92.5(0,88 ; 0,96)$ \\
G2 & $100(0,99 ; 1,00)$ & $100(0,99 ; 1,00)$ & $100(0,99 ; 1,00)$ & $99.4(0,98 ; 1,00)$ & $99.4(0,98 ; 1,00)$ & $98.2(0,96 ; 1,00)$ \\
G3 & $80(0,73 ; 0,86)$ & $100(0,99 ; 1,00)$ & $100(0,99 ; 1,00)$ & $97.2(0,94 ; 0,99)$ & $96.5(0,96 ; 0,99)$ & $96.5(0,96 ; 0,99)$ \\
\hline
\end{tabular}

Table 2: prevalence presumptive active syphilis (TPHA+VDRL $1: 8$ )

\begin{tabular}{|lrrr|}
\hline \multicolumn{5}{c|}{ Prevalence } \\
& whole blood & Serum & Plasma \\
G1 & 0.006 & 0.006 & 0.006 \\
G2 & 0.006 & 0.006 & 0.006 \\
G3 & 0.034 & 0.034 & 0.034 \\
\hline
\end{tabular}

Table 3: The kappa coefficient for correlation between the reference TPHA+VDRL r:8 test and the DPP ${ }^{\circledR}$ Syphilis Screen \& Confirm

\begin{tabular}{|cccc|}
\hline \multicolumn{4}{c|}{ Kappa coefficient } \\
Gi & whole blood & Serum & Plasma \\
$\mathrm{G}_{2}$ & 0,134 & 0,115 & 0,124 \\
$\mathrm{G}_{3}$ & 0,664 & 0,664 & 0,394 \\
\hline
\end{tabular}




\section{Discussion}

This study aimed to evaluate the performance of the DPP ${ }^{\circledR}$ Syphilis Screen \& Confirm BioManguinhos Assay in the whole blood, sera, and plasma in three groups of patients: infected with HIV, pregnant women, and neither pregnant nor HIV infected.

The procedure for syphilis research in Brazil during the prenatal period is the venous sample collection to perform non-treponemal test for screening of pregnant women. Generally, this test if present positive, the sample is subjected to the treponemal test for confirmation. Our national policy recommends three VDRL tests in pregnant women: two during prenatal care and one during the childbirth.

In comparison to the testing algorithm for traditional diagnosis of syphilis, where a positive result for the VDRL test on sample diluted i: 8 was confirmed by a treponemal test (TPHA), we used TPHA+VDRL i:8 as the gold standard for the diagnosis of active syphilis. In this case, the only pregnant woman who got positive results for this gold standard also tested positive for the simultaneous detection of treponemal line $\mathrm{T}_{\mathrm{I}}$ and nontreponemal line $\mathrm{T}_{2}$, for all sample types tested (whole blood, serum and plasma).

This performance of DPP ${ }^{\circledR}$ Syphilis Screen \& Confirm Bio-Manguinhos Assay in whole blood of pregnant women shows the advantages of its use in prenatal consultation. The realization of this rapid test for pregnant women and their partners, in the first prenatal consultation, can reduce the loss of follow-up of these pregnant women. The DPP ${ }^{\circledR}$ Syphilis Screen \& Confirm BioManguinhos Assay get diagnostic response of active syphilis within 30 minutes, with no need to wait for laboratory response. There is not also the need for further consultation schedule to inform the diagnosis and the treatment can be started immediately without having the risk of losing the case.

The prevalence rates for syphilis from prior studies were 3.6\%, $2.7 \%$, and $3.4 \%$ in pregnant women, patients infected with HIV, and neither pregnant nor HIV infected, respectively (I4, I5, 16). After the study, the prevalence rate for syphilis in neither pregnant nor HIV infected group was confirmed. However, the actual prevalence rate in pregnant women and patients infected with HIV was $0.6 \%$ (Tab. 2). An operational explanation for this given real prevalence found is the fact that 53.57\% of pregnant women were recruited at the Hospital Maternity Carmela Dutra. This hospital recorded in 20II, 725 visits per month, an average of 9 cases per month of pregnant women with positive diagnosis of syphilis. This means a prevalence of $1.2 \%$ in this maternity, three times lower than the national prevalence.

The diagnostic tests are frequently validated in hospital environments where the prevalence of the disease to be tested is normally high. However, the diagnostic test can often be used in primary 
care clinics where the prevalence is lower. As exemplified in Figure I, in different locations with different prevalence rates for the disease, the sensitivity and specificity of the test can be the same, but the positive predictive value can be very different. This is simply because in low prevalence areas, there are very few cases to be identified and many more non-cases in the context of primary care. Thus, if the specificity is not very high, the number of false positives may exceed the true positives. Similarly, the lowest prevalence means that a negative test result is more accurate and so the doctor can reassure your patient informing him that it is very unlikely that he has the disease. In these cases, the physician should remind him to return for reassessment his symptoms, as he can be one of the few patients with a false negative result.

\begin{tabular}{|c|c|c|c|c|c|}
\hline & \multicolumn{5}{|c|}{ Clinical setting } \\
\hline \multicolumn{3}{|c|}{$\begin{array}{l}\text { Specialist referral hospital } \\
\text { (high prevalence) }\end{array}$} & \multicolumn{3}{|c|}{$\begin{array}{c}\text { Primary care } \\
\text { (low prevalence) }\end{array}$} \\
\hline \multicolumn{3}{|c|}{$\begin{array}{l}\text { Disease } \\
\text { present } \quad \text { absent }\end{array}$} & \multicolumn{3}{|c|}{$\begin{array}{l}\text { Disease } \\
\text { present } \mid \text { absent }\end{array}$} \\
\hline test - & & 10 & test + & 50 & 100 \\
\hline test - & & 100 & test - & 5 & 1000 \\
\hline \multicolumn{3}{|c|}{$\begin{array}{l}\text { Sensitivity }=50 / 55=91 \% \\
\text { Specificity }=100 / 110=91 \%\end{array}$} & \multicolumn{3}{|c|}{$\begin{array}{l}\text { Sensitivity }=50 / 55=91 \% \\
\text { Specificity }=1000 / 1100=91 \%\end{array}$} \\
\hline \multicolumn{3}{|c|}{ Prevalence $=55 / 165=33 \%$} & \multicolumn{3}{|c|}{ Prevalence $=55 / 1155=3 \%$} \\
\hline \multicolumn{3}{|c|}{$\begin{array}{c}\mathrm{PPV}=50 / 60=83 \% \\
\mathrm{NPV}=100 / 105=95 \%\end{array}$} & \multicolumn{3}{|c|}{$\begin{array}{c}\mathrm{PPV}=50 / 150=33 \% \\
\mathrm{NPV}=1000 / 1005=99.5 \%\end{array}$} \\
\hline
\end{tabular}

Figure I: The impact of prevalence on predictive values of a diagnostic test, comparing a high prevalence setting (specialist referral hospital) with a low prevalence setting (primary care). Reprinted from AFMC Primer on Population Health: A virtual textbook on Public Health concepts for clinicians (I8).

All analyzes in the group of pregnant women, compared to the DPP ${ }^{\circledR}$ Syphilis Screen \& Confirm Assay in whole blood and reference tests, individual or combined, showed Kappa values above 0.61 , characterizing the correlation between the tests as "substantial". However, when we observed the kappa indexes of some tests, the kappa rates are lower; despite the rapid tests present a high correlation with the reference test. In the group infected with HIV the samples whole blood, serum and plasma were reactive for both Treponemal and non-Treponemal antibodies, compared with the reference test TPHA+VDRL i:8, with kappa indexes of 0.134, 0.115 and 0.124, respectively (tab. 3). 
Many researchers are not aware of a major disadvantage in using the kappa index. Similarly to the predictive values are affected by the prevalence is also kappa. In the evaluation of diagnostic markers, certain tests appear to have high sensitivity and specificity, can have low predictive value when the prevalence is low. Similarly, two assays that appear to have a high correlation may still emerge with low values of kappa due to problems to low prevalence (19,20,21).

We found four other studies of DPP Syphilis Screen \& Confirm Assay, (22,23,24,25). , which used Treponema pallidum particle agglutination (TPPA) assay, toluidine red unheated serum test (TRUST), and rapid plasm regain (RPR) as reference standards. We avoid compare the results because the behavioral risk groups in other studies were differently defined.

Another result to be better analyzed is the sensitivity of $80 \%$ found in whole blood of neither pregnant nor HIV infected individuals. This loss of sensitivity in whole blood samples can be associated to an increased need of technical training aiming identify and prevent errors in the testing process.

This study has allowed us to conclude that the DPP Syphilis Screen \& Confirm Assay has advantages when compared to using traditional test VDRL / RPR and TPHA. These tests require a minimum laboratory structure, which often prevents their use in remote locations. In addition, many patients do not normally return to the laboratory to receive the results of these examinations, preventing their treatment. The use of the rapid test DPP Syphilis Screen \& Confirm Assay prevent the loss of these patients once in 20 minutes physician have diagnosis of active syphilis, may start treatment immediately, beyond the fact of having satisfactory performance in the groups tested, when compared to the current algorithm testing of Brazilian Ministry of Health

\section{Footnotes}

${ }^{a}$ Ministério da Saúde. Bol Epidemiol Sifilis. 2012 [cited 2013 Sep I];I(I). Available from:http://www.aids.gov.br/sites/default/files/anexos/publicacao/2012/52537/boletim_sifilis_20I 2_pdf_26676.pdf

\section{References}

I) Brasil. Boletim Epidemiológico - Aids e DST - Ano VIII - $n^{\mathrm{o}}$ I $-27^{\underline{a}}$ a $52^{\underline{a}}$ - semanas epidemiológicas - julho a dezembro de 2010 - Ano VIII - no I $^{-}$oI $^{\underline{a}}$ a $26^{\underline{a}}$ - semanas epidemiológicas janeiro a junho de 20II. Programa Nacional de DST/AIDS e Hepatites Virais. Ministério da Saúde

2) Brasil. Prevalências e frequências relativas de Doenças Sexualmente Transmissíveis (DST) em populações selecionadas de seis capitais brasileiras, 2005. Programa Nacional de DST/Aids e Hepatites Virais. Ministério da Saúde, 2008. 
3) Castro AR, Esfandiari J, Kumar S, Ashton M, Kikkert SE, Park MM, Ballard RC. Novel pointof-care test for simultaneous detection of nontreponemal and treponemal antibodies in patients with syphilis. J Clin Microbiol. 2010; 48(12): 4615-9.

4) Causer LM, Kaldor JM, Fairley CK, Donovan B, Karapanagiotidis T, Leslie DE, Robertson PW, McNulty AM, Anderson D, Wand H, Conway DP, Denham I, Ryan C, Guy RJ. A laboratorybased evaluation of four rapid point-of-care tests for syphilis. PLoS One. 9; e 91504.

5) Centers for Disease Control and Prevention. Sexually Transmitted Disease Surveillance 2007 Supplement, Syphilis Surveillance Report. Centers for Disease Control and Prevention. Centers for Disease Control and Prevention. Available at http://www.cdc.gov/std/Syphilis2007/. Accessed: April I4.

6) Chembio Diagnostic Systems Inc., DPP ${ }^{\circledR}$ Syphilis Screen \& Confirm product information sheet, 2009 .

7) Cicchetti DV and Feinstein AR. High agreement but low Kappa: II. Resolving the Paradoxes. Journal of Clinical Epidemiology. 1990; 43(6): 551-558.

8) De Lorenzi DRS, Madi JM. Congenital Syphilis as a Prenatal Care Marker. Rev. Bras. Ginecol. Obstet. 2001; 23(10): 647-652.

9) Domingues RMS, Saraceni V, Hartz ZMA, Leal MC. Sífilis congênita: evento sentinela da qualidade da assistência pré-natal. Rev Saude Publica. 2013;47(I):147-57. DOI:10.1590/Soo348910201300orooorg.

Io) Esfandiari J, Gunasekera D, Sayegh F, Addiss K, Sikar-Gang A, Performance Evaluation of the DPP(R) HIV-SYPHILIS Assay: a novel, point-of-care rapid HIV I/2, and Syphilis Treponema pallidum Antibody Combination Test. 2012; HIV Diagnostics Conference, Atlanta, GA.

II) Genç M, Ledger WJ. Syphilis in pregnancy. Sex Transm Infect. 2000; 76:7379 doi:10.1136/sti.76.2.73.

I2) Hess KL, Fisher DG, Reynolds GL. Sensitivity and Specificity of Point-of-Care Rapid Combination Syphilis-HIV-HCV Tests. PLoS One. 2014; Mar Ir;9(3): e91504.

13) IBM Corp. Released 20II. IBM SPSS Statistics for Windows, Version 20.o. Armonk, NY: IBM Corp.

14) Komagata N. 2002. Chance agreement and significance of the kappa statistic. [Online]. Available: www.tcnj.edu/\%7Ekomagata/ pub/kappa.pdf. [June 30, 2016].

I5) Kraemer HC. Ramifications of a Population Model for Kappa as a Coefficient of Reliability. Psychometrika. 1979; 44(4): 46I-472.

16) Morshed MG, Singh AE. Recent trends in the serologic diagnosis of syphilis. Clin Vaccine Immunol. 2015; 22:137-147.

17) Nayak S and Basanti Acharjya B. VDRL Test and its Interpretation. Indian J Dermatol. 2012 Jan-Feb; 57(I): 3-8.

8) Parikh R, Mathai A, Parikh S, Sekhar GC, Thomas R. Understanding and using sensitivity, specificity and predictive values. Indian J Ophthalmol. 2008; 56(I): 45-50.

9) Peeling RW. Testing for sexually transmitted infections: a brave new world? Sex Transm Infect. 2006; 82(6): 425-430. 
2o) Rodrigues CS, Guimarães MDC, César CC. Missed opportunities for congenital syphilis and HIV perinatal transmission prevention. Rev Saude Publica. 2008;42(5):851-8. DOI:10.1590/Soo3489102008000500010

21) Signorini, DJHP. Prevalência da co-infecção HIV-sífilis em um hospital universitário da cidade do Rio de Janeiro no ano de 2005. Rev. Soc. Bras. Med. Trop. 2007; vol.40 no 3. Uberaba Maio/Junho, 2007.

22) Szwarcwald CL, Barbosa Jr A, Miranda AE, Paz LC. Resultados do Estudo SentinelaParturiente, 2006: desafios para o controle da sífilis congênita no Brasil. DST - J Bras Doenças Sex Transm. 2007;19(3-4):128-33.

23) The Association of Faculties of Medicine of Canada. Chapter 6: Methods: Measuring Health. In: AFMC Primer on Population Health: A virtual textbook on Public Health concepts for clinicians. Available from URL: http://phprimer.afmc.ca/Part2MethodsStudyingHealth/Chapter6MethodsMeasuringHealth/Interpretingtestsonindividuals.

(Accessed June 30, 2016).

24) Yin YP, Chen XS, Wei WH, Gong KL, Cao WL, Yong G, Feng L, Huang SJ, Wang DM, Han Y, Chen SC, Mabey D, Peeling RW. A dual point-of-care test shows good performance in simultaneously detecting nontreponemal and treponemal antibodies in patients with syphilis: a multi-site evaluation study in China. Clin Infect Dis. 2013; 56: 659-665. 